\title{
The International Energy Strategies Ruling the Middle East for a Century Re-appear and Determine the Destiny of the Whole Eastern Mediterranean Region
}

\author{
Aref Alobeid \\ Ph.D. of Political Science and History, \\ Panteion University of Athens, Greece \\ loannis Vidakis \\ Ph.D. of Business School, \\ University of the Aegean, Chios, Greece \\ Georgios Baltos
}

Ph.D.(c) of Business School, University of the Aegean, Chios, Greece

\section{Janis Balodis}

MA student, Belarusian Economic Research and Outreach Center (BEROC), Minsk, Belarus

Doi: 10.2478/mjss-2018-0133

\section{Abstract}

This paper examines the involvement of Western powers in the politics of Caucasus and Mesopotamia regions around the beginning of the 20th century. It attempts to identify the ideological background of the respective historical events whirled around the geopolitical and geo-economics aspirations of the super powers of that era. The motives of the relevant tremendous investments and campaigns undertaken do not always coincide with the rhetoric and the rationale provided by politicians and spokesmen favoring the expeditions. On one hand scholars were metaphorically reviving the clash of civilizations or the crusades re-launch, while on the other hand politicians and businessmen were taking advantage of the cultural stereotypes in order to facilitate colonial interests and energy resources acquisition. All the way from the early British interventions in the Middle East to the causes of the "fragile" Treaty of the Sèvres, this study emphasizes on the industrial countries' needs for oil along with the rivalry among the Great Powers for the resources control in the region. In addition, the analysis ends at the present time with a focus on the periodicity of the events taking place in repetition under similar patterns. The projection to the present times involves newly designed energy strategies for the Eastern Mediterranean basin, involving Cyprus in an alternative way to transfer energy toward Southern Europe.

Keywords: Oil, Energy Strategy, European Energy Security, Middle East, Geo-energy

\section{Introduction}

The emergence of the industrial revolution in Europe is considered to be one of the key points in the history of the modern world. The demand for raw materials along with the need to open new 
markets had sparked the era of colonialism in the Middle East and Africa (Wringley 2017). In addition, the discovery of energy fossil fuels, e.g. oil and natural gas, had resulted in strong competition between the European Great Powers of that time. This rivalry had resulted in many negative consequences for the people of the back then less developed countries, such as wars, invasions and occupations, exploitation of national wealth, borderlines' disputes and re-drawing of the geographic maps (Vidakis 2015).

The case of the Middle East over the whole duration of the $20^{\text {th }}$ century is indicative of these geopolitics and "geo-energeia" patterns that ruled the world politics and contributed into the world wars development. Great Britain was a protagonist of the pre-cold war era as well as a main actor of the world's colonial history. It was being highlighted that "the sun never sets" over the vast areas that it controlled (Kagan 1998). Soviet historians described though the British energy policies as imperialist aggression (Qasimly 2006). On the other side, in the capitalist world, major emphasis was theoretically given on the class of civilizations as a catalyst of the Middle Eastern dynamic conflicts and turmoil (Huntington 2007). In this line, "jihad" and "crusade" were running in parallel, at least at a propaganda level or in the hearts and minds of a lot of people massively involved, fuelling up for centuries the famous Eastern question, i.e. which civilizations, religions or ethnicities will fill up the power vacuum extended around the Middle eastern area that major global and regional powers call their own "Holy Land".

\section{A Geo-historical Review of the 20th Century International Energy Chessboard}

This paper attempts to shed light on the energy policy of the Great Powers in the area of Middle East since the World War I, therefore the research question is being discussed around the geoenergy and geo-economics motivation of the main protagonists. However, the geo-cultural aspects are also considered critical, since they shape public opinions and mobilize the societies which contribute the soldiers to populate the armies and materialize the leadership strategies and policies. Especially the British command itself, in the context of its imperial superpower during that era, is worthy to be studied as a predominant paradigm of diplomacy and military exercise, since it had eventually, like no other before, realized the economic importance of fossil fuels for the purposes of conducting military operations toward the ultimate achievement of global domination, while at the same time it was lacking, apart from the old "coal kingdom", relevant resources on its own land. Upon this realization, a long-lasting pursuit of the British, among others, became the acquisition and/or control of petroleum-rich territories (Vidakis, Baltos \& Balodis 2017).

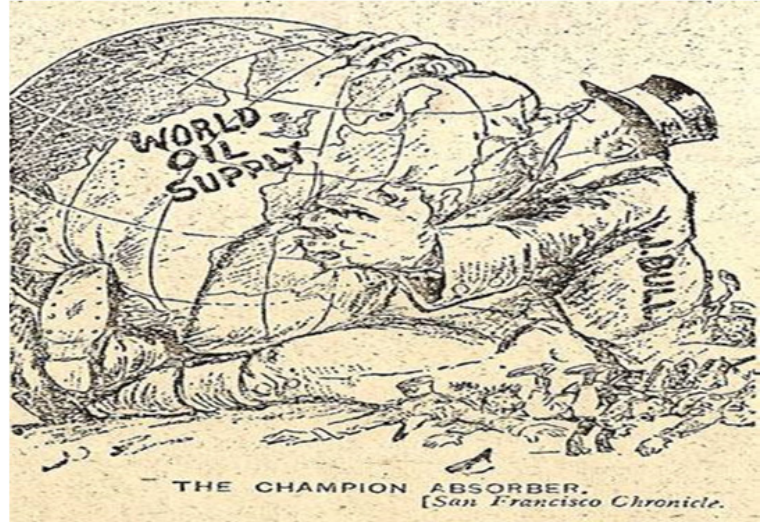

Fig. 1. G. Britain (personified as “John Bull”) and Petroleum (Mascarenhas 2014)

The British accomplishments draw further attention, given that the Russian Empire as a competitor was in possession of rich oil wells around Baku area, at the present-day Azerbaijan; moreover, 
significant domestic resources of crude oil were discovered in the USA. The British tried to compensate this weakness of lacking energy resources on its own territory by taking advantage of not only every opportunity presented to them at their colonies, but also by being active in distant regions such as Burma/Myanmar, Indonesia, Mexico, along with the nearest territories of Persia/Iran, Mesopotamia and Caucasus. Fig. 1 above, as early as 1916, while WWI was still ongoing, characteristically depicts how this pursuit was portrayed in the United States, no matter that the latter were themselves the international champion in the production of the global crude oil supplies. Under those circumstances, Ottoman Empire took the place of the "Sick man of Europe", after it had survived for many decades in the context of a geopolitical equilibrium respected by the Europeans and containing the Russians to accomplish occupation and control of Constantinople and the Straits (Çırakman 2002). However, with the first confirmation of the existence of rich deposits of oil in the grounds of the Sublime Porte, the war drums began to sound in Kirkuk and then in Mosul. Just afterwards the European Great Powers opted for acquisition and exploitation of rich Mesopotamian resources (Vidakis and Baltos 2015). Characteristically, the diplomatic document No. 63, drafted as a guide to British diplomats who attended the conference towards the Treaty of Lausanne in 1923, contained the following statement: "A German expert who visited the oil-fields of Mosul and Baghdad in 1901 said that these were among the richest in the world" (Bierstadt and Creighton 1924).

The British Empire, particularly, had already been able to secure the oil of the neighbouring to the Ottoman Empire Persia, although the extracted quantities did not meet its requirements (Antonius 2015). In addition, the British strategically supported their allies, granting preferential agreements, e.g. the establishment of the Arab states, the early surrender of Mosul into the French sphere of influence, the liberation of İzmir by the Greeks, the formation of independent Armenia and Kurdistan, etc. (Siusiuras and Kutsukes 2012). These known negotiations carried out during the period 1915-1916 between Hussein, the Mecca Emir as representative of the Arabs, and McMahon, a representative of Britain in Egypt and Sudan, in order to determine how to cooperate and demarcate the borders of the "new" Arab states after the end of the war (Holt 1966).

However, in the end, slowly but persistently, they managed to impose their own will in the region and prevent the advance of their geopolitical and economic allies, but also competitors, Russia and France from implementing these projects (Hurewitz 1975). The Sykes and Picot agreement between France and Britain is considered one of the most controversial arrangements ever concluded in modern colonial history. Furthermore, this agreement attempted to give a decisive end to the "Eastern question" (Vidakis 2016).

TREATY OF SEVRES

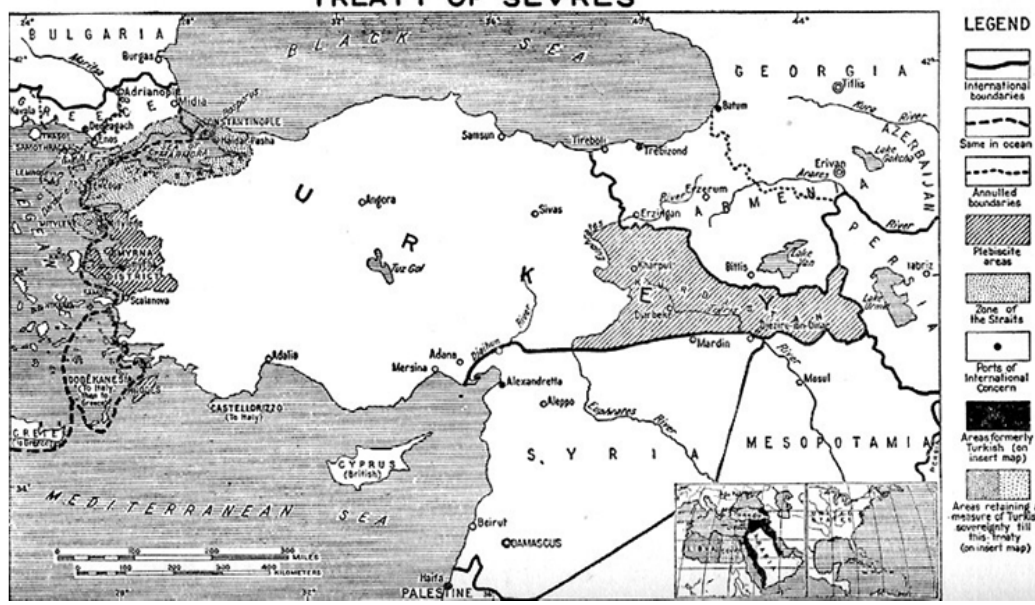

Fig. 2. The Ottoman Empire according to the Treaty of Sevres (Carnegie Endowment for International and Martin 1924) 


\section{Global Geo-Energy Rivalry}

In addition, the Allied Western powers apart from their energy strategic initiatives in regard with the oil of Mesopotamia accepted the establishment of a Turkish state, secular but not Muslim as the successor to the Ottoman Empire and a barrier to the Soviet Union expansionism (Vidakis and Baltos 2013). This policy was maintained by the United States after World War II as Greece and Turkey both received assistance and were accepted into NATO as allies, ensuring the flow of oil from the Middle East to the West and keeping the Soviets away from the "warm" Mediterranean waters (MacGwire 1988).

The Arabs were engaged in a difficult energy chess game, facing difficulties that it seems ended up in troubles stemming out of the so-called phenomenon of "Oil Curse", i.e., while natural resources should be, financially and technically, considered a national privilege, sometimes drive the nations into geopolitical dependencies and subordination (Ross 2012). Meanwhile, through outsmarting their French allies, the British succeeded in their quest for crude oil in the Middle East, as it was proved at the San Remo Conference. Even more, the above-mentioned arrangement between Britain and France had excluded the USA and its oil companies from the region's energy sources. In 1924 the "Compagnie Francaise des Petroles" (Total) was formed to take over the French share in Mesopotamia (Sassi 2006).

\section{USA Reaction - The "Red Line" Agreement}

Before the end of the 1920s, the American press had denounced the Anglo-French deal described above as an act of "old-fashioned imperialism" (Carson 2007). Washington started to consider implementing some sanctions against its "ungrateful" allies. Thus, the relationship between Washington and London went through a crisis. Furthermore, Allen Dulles, a legal advisor at the State Department, wrote a memorandum, insisting that the agreement on land concession with the Turkish Petroleum Company, given the divided status of the Ottoman Empire, was legally void and should not be recognized by the United States. Indeed, with the United States being powerful enough not to be ignored, London had soon succumbed to the transatlantic pressure and announced that it was ready for an agreement that would give the United States (USA) a "fair" share (Hogan 1974). Lord Curzon, the British Foreign Secretary protested that Great Britain also believed in the "Open-Door" policy. The Americans, in this way, managed for the Standard Oil to execute oil mining in Palestine, which was under British control even before the WW I (Pankhurst 1922).

The petroleum disputes ended in the Middle East with the 1928's distribution agreement. One of its clauses was to establish a joint oil company between the British, French, Dutch and Americans, with the help of the businessman C.S. Gulbenkian. This company was made up of the Anglo-Persian Oil Company, the Royal Dutch Shell, Compagnie Française des Pétroles (Total), Near East Development Corporation (a group of five USA companies) with a $23,75 \%$ share and Calouste S. Gulbenkian's share of $5 \%$ (Campbell 2005). This agreement included the "Red Line" clause: a red line was drawn on the map, outlining the area in which none of the parties had the right to obtain exclusive permission for the exploration and mining of oil. That forbidden zone included the entire Arabian Peninsula (with the exception of Kuwait and Sinai), Asia Minor and Cyprus. The agreement had been maintained until the WWII. The red line was drawn freely as a reference to a USA Federal Trade Commission map, which was included in a report titled "The International Oil Cartel", submitted to the Subcommittee on Monopolies of the Small Business Inquiry Committee of the United States Senate (Blair 2013). 


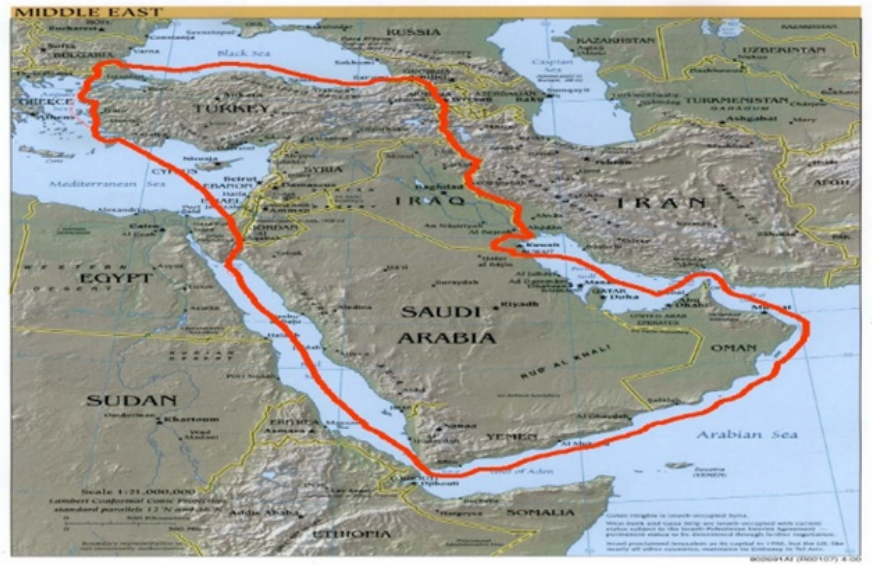

Fig. 3. The Red Line Agreement (Blair 2013)

In the context of this Red Line Agreement, the USA government initially supported the creation of the Great Armenia, integrating the Batumi \& Baku oil fields into it, as well as the establishment of the Kurdish state, with a view to integrate the oil fields of Mosul and Kirkuk into it. In addition, the Turkish National Assembly had endorsed the so-called Chester Concession as an aid to Turkey (Bierstadt and Creighton 1924). Thus, the main American privileges from that certain approach to the "resolution" of the Eastern issue were the concessions of several Turkish regions into the USA sphere of interests for 99 years, the construction of two ports and railway lines $3.600 \mathrm{~km}$ long, the grant of mining rights within $20 \mathrm{~km}$ on both sides of the line, the reconstruction works' contracts of a worth between $\$ 200$ and $\$ 300$ million, as well as the exploitation of other natural resources and mines. That specific example is clearly indicating how the exodus out of WWI implied a huge geoenergy struggle of the powers involved to secure access to sufficient energy sources (Vidakis 2016).

\section{In the aftermath of World War II}

The new situation that took shape after the WWII, displayed two pre-existing conflicts. The first was between the capitalist West and the communist East, with Britain adopting a 1950's military plan to re-establish and reinforce a buffer zone as defense against a possible Soviet attack on the Middle East; the Syrian lands were included in this zone. Between 1951 and 1953, Western countries began discussions about the setup of the Middle East Defense Organization (MEDO) to counter the international spread of communism (Hale 2012). However, the Suez Canal Crisis in 1956 meant the definitive withdrawal of the two historic Great Powers, France and Britain, from the Middle East as well as the dynamic entry of the USA as the superpower to fill the power gap. Because of this, the American leadership announced the Eisenhower doctrine in 1957, in order, among several objectives, to secure the Western interests around the energy resources of the region (Hammond and Alexander 1972).

The second conflict, which had interestingly not drawn the media attention as much as it deserved, was among the Western countries themselves, mainly over the control of the energy resource ducts. For instance, the Aramco group, serving American interests, wanted to build the Tapeline pipeline from Saudi Arabia's al-Zaharan district to the Mediterranean, via Syria and Lebanon. The Tapeline's competitor in the Middle East was the MEPL pipeline of British interests, that would transit oil from Iran to the Mediterranean Sea. But this inter-western competition finally ended in favor of the Tapeline and revealed the hidden conflict of interests that had existed in the underground of British-American relations (Karkazis, Vidakis, and Baltos 2014). 


\section{Risk Mitigation and the East Med Alternative}

Energy management is dependent on socio-economic changes that are all projected on the geographic maps. That is why the interaction of energy, economy and politics has triggered lately multiple discussions on the question whether we should study the geopolitics of energy or the geoenergy of politics (Vidakis, Baltos \& Balodis 2017). All the turmoil discussed before around the Mesopotamian resources as the epicenter of contradictory interests is being already circumvented in order to fuel Europe in the most efficient and as safe as possible ways. A. Alobeid and I. Vidakis (Alobeid and Vidakis 2017) recently presented an alternative route away from the military operations theatre of the Syrian civil war or Iraqi and Iranian energy security concerns.

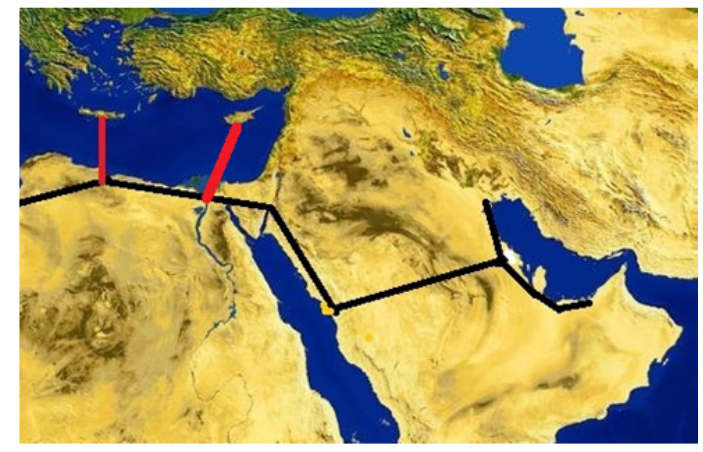

Fig. 4. The proposed East Med Stream pipeline. Source: elaborated by the writers

The strengths of such a proposal can be considered as it follows (Alobeid 2016). Firstly, given the undeclared war between Saudi Arabia and Iran and the gaps in the Arab security system, the Arab Countries of the Gulf are looking for secure and innovative ways to export their huge oil and gas reserves to the West (Manama 2016). Secondly, the geography of this area is well suited to pipeline construction, specifically, from the western shores of the Arab-Persian Gulf to the last point on the north-western borders of Egypt, keeping in mind the existing infrastructure in that area. Thirdly, the adoption of such a pipeline will protect the Gulf countries from security threats due to the negative attitudes demonstrated in the past by certain governments, mainly the Syrian, which forbade the transit of oil through Syrian territories for many years (Karkazis, Vidakis, and Baltos 2014).

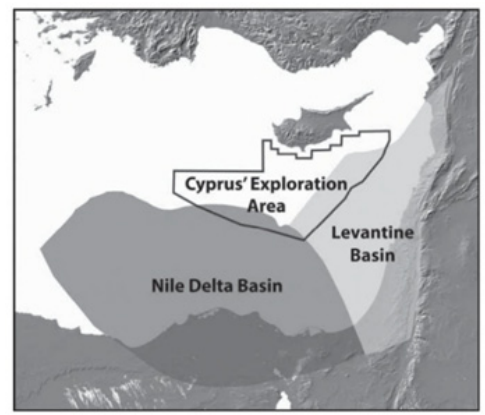

Fig. 5. The respective discoveries in the eastern Mediterranean are considered crucial for serving future EU needs (Petasis 2016)

The so called East Med energy corridor has attracted already attention and investments. The respective discoveries in the eastern Mediterranean basin are considered crucial for serving future 
European Union (EU) needs, diversifying the energy routes for security and efficiency purposes (Baconi 2017). Nevertheless, there are commercial and political hurdles on the way. Cyprus, Israel and Egypt have initiated a regional cooperation toward mid-term exports. Table 1 below depicts the estimated data on the discovered and yet to be discovered quantities.

Table 1. Natural gas volumes estimations in the offshore Eastern Mediterranean Sea (Tagliapietra 2013)

Natural gas volumes in the offshore eastern Mediterr
(discovered and yet-to-find)
\begin{tabular}{|c|c|}
\hline \multicolumn{2}{|c|}{ Egypt } \\
\hline Nile Delta Province & $6310 \mathrm{bcm}$ (yet-to-find) \\
\hline \multicolumn{2}{|c|}{ Israel } \\
\hline Leviathan & $476 \mathrm{bcm}$ \\
\hline Tamar & $250 \mathrm{bcm}$ \\
\hline Dolphin & $2 \mathrm{bcm}$ \\
\hline Dalit & $14 \mathrm{bcm}$ \\
\hline Tanin & $33 \mathrm{bcm}$ \\
\hline Mari-B & $30 \mathrm{bcm}$ \\
\hline Noa & $1 \mathrm{bcm}$ \\
\hline \multicolumn{2}{|c|}{ Cyprus } \\
\hline Aphrodite & $140-220 \mathrm{bcm}$ \\
\hline Gaza \\
\hline \multicolumn{2}{|c|}{ Lebanon } \\
\hline Phase 1 & $672 \mathrm{bcm}$ (yet-to-find) \\
\hline Total East Med & 8014 bcm \\
\hline
\end{tabular}

U.S. Geological Survey, Energy Intelligence and companies' information

\section{Conclusions and Policy Implications}

The discovery of significant natural gas resources in Egypt's Exclusive Economic Zone (EEZ) could encourage the Egyptians to help build a part of this pipeline and guarantee its safety in order to export their natural wealth to the EU countries (Hafner, Tagliapietra, and Elandaloussi 2012). A fortified EU energy diplomacy may firstly realize the significance of the resources available just on the edge of its periphery. East Med may alleviate EU gas dependence on Russian imports and Turkish transit (Tsakiris 2014).

In conclusion, the realization of the East Med Stream concept could, to a large extent, reset the rules and the figures of the "energy game" in the Eastern Mediterranean, since, as it is estimated, it could account for the transit of as much as $50 \%$ of the world's energy reserves, fulfilling the ambitions of Middle Eastern countries to transport energy resources to the West, transforming stable and secure EU territories into an energy gateway, equipped with an international liquefied natural gas station for the needs of EU and the Balkans. The international energy strategies ruling the Middle East for a century periodically re-appear, but at this time the resources epicenter has been shifted to the south-eastern waters of Cyprus (see Fig. 5, above), implying polices of energy security, EU geo-economic efficiency and diversification as well as international cooperation distant to the traditional Middle Eastern war zones.

\section{References}

Alobeid, A., Vidakis, J. (2017). International Energy Strategies in Middle East. Foreign Affairs - Hellenic Edition, 45, 108-123.

Alobeid, A. (2016). Geo-Strategies of the Middle East. Vari. SSE Attica. 
Antonius, G. (2015). The Arab awakening: The story of the Arab national movement. Washington: Pickle Partners Publishing.

Baconi, T., European Council on Foreign Relations, \& European Council on Foreign Relations Staff (2017). Pipelines and Pipedreams: How the EU Can Support a Regional Gas Hub in the Eastern Mediterranean. European Council on Foreign Relations.

Bierstadt, E. H., \& Creighton, H. D. (1924). The great betrayal: a survey of the near East problem. Newcastle upon Tayne: McBride \& Company.

Blair, J, M., (2013), The Red Line Agreement. [Online] Available: https://www.mtholyoke.edu/acad/intrel/Petroleum/redline.htm (April 17, 2018)

Campbell, C. J. (2005). Oil Crisis. Multi-Science Publishing Company.

Carnegie Endowment for International, Peace, and Lawrence Martin. (1924). The treaties of peace, 1919-1923. vol. I. Containing the Treaty of Versailles, the Treaty of St. Germain-en-Laye and the Treaty of Trianon. (Vol. II. Containing the Treaties of Neuilly and Sèvres, the treaties between the United States and Germany, Austria and Hungary respectively, and the Treaty of Lausanne, the convention respecting the regime of the Straits and other instruments signed at Lausanne). New York.

Carson, T. (2007). Gilligan's Wake: A Novel. Picador.

Çırakman, A. (2002). From the "terror of the World" to the "sick Man of Europe": European Images of Ottoman Empire and Society from the Sixteenth Century to the Nineteenth. Peter Lang Publishing.

Hafner, M., Tagliapietra, S., \& Elandaloussi, El, H. (2012), Outlook for oil and gas in southern and eastern Mediterranean $\quad$ countries. $\quad$ Anline] http://www.medproforesight.eu/fr/system/files/MEDPRO\%20TR\%20No\%2018\%20WP4b\%20Hafner\%20et\%20al_0.pdf (April 12, 2018)

Hale, W. (2012). Turkish foreign policy since 1774. London: Routledge.

Hammond, P. Y., \& Alexander, S. S., (1972). Political dynamics in the Middle East. Amsterdam: Elsevier Publishing Company.

Hogan, M. J. (1974). Informal Entente: Public Policy and Private Management in Anglo-American Petroleum Affairs, 1918-1924. Business History Review, 48, 187-205.

Holt, P, M., (1966). Egypt and the Fertile Crescent, 1516-1922: a political history. Ithaca: Cornell University Press.

Huntington, S.P. (2007). The Clash of Civilizations and the Remaking of World Order. Simon \& Schuster.

Hurewitz, J., C., (1975). The Middle East and North Africa in World Politics. New Haven, CT: Yale University Press.

Kagan, R. (1998). The benevolent empire. Foreign Policy, 111, 24-35.

Karkazis, J., Vidakis, I., \& Baltos, G. (2014). The Syrian Energy Policies of the "Four Seas" and Their Geopolitical Repercussions. Sosyoekonomi, 22, 105-116.

Manama, B. (2016), Economic Diversification in Oil-Exporting Arab Countries. [Online] Available: https://www.imf.org/external/np/pp/eng/2016/042916.pdf (April 12, 2018)

Mascarenhas, H. (2014), How the British Screwed Up the Middle East, in 10 Classic Cartoons. [Online] Available: $\quad$ https://mic.com/articles/91071/how-the-british-screwed-up-the-middle-east-in-10-classiccartoons\#.29eSwS54B (April 17, 2018)

Mccgwire, M. (1988). Soviet strategic aims and capabilities in the Mediterranean: Part I. In Robert O'Neill, R. (Ed.), Prospects for Security in the Mediterranean (pp. 14-48). Springer.

Pankhurst, Sylvia, (1922), The Truth about the Oil War, Dreadnought Publications. [Online] Available: http://www.marxists.org/archive/pankhurst-sylvia/1922/oil-war.htm (April 17, 2018)

Petasis, A. (2016). Intractable Dilemmas in the Energy-Rich Eastern Mediterranean. Cambridge: Cambridge Scholars Publishing.

Qasimly, M., (2006), Britain's Azerbaijan Policy (November 1917 - September 1918), Visions of Azerbaijan. [Online] Available: http://www.visions.az/en/news/151/cf8230fa/ (April 17, 2018)

Rathmell, A. (1995). Secret War in the Middle East: The Covert Struggle for Syria, 1949-1961. London: St. Martin's Press.

Ross, M. L. (2012). The oil curse: how petroleum wealth shapes the development of nations. Princeton University Press.

Sassi, M. (2006). Compagnie Francaise des Pétroles and Its Contribution to the Re-establishment of France's Position among the Oil Countries after the Second World War. Paris: Dictionnaire historique des patrons francais.

Siusiuras, P., P., and Kutsukes, K. S. (2012). Geopolitike kai zotikos choros : e Mikrasiatike Ekstrateia kai o antagonismos ton Megalon Dynameon. Athena: Ekd. I. Sideres.

Tagliapietra, S. (2013), Towards a New Eastern Mediterranean Energy Corridor? [Online] Available: https://papers.ssrn.com/sol3/papers.cfm?abstract_id=2220638 (April 17, 2018)

Tsakiris, A. (2014), Greece and the energy geopolitics of the Eastern Mediterranean, LSE Research Online. [Online] Available: http://www.Ise.ac.uk/IDEAS/Home.aspx (April 17, 2018) 
Vidakis, I., (2016). Energy Network's Security in the Eastern Mediterranean. Doctoral Thesis, Chios: Department of Shipping, Trade and Transport, School of Business, University of the Aegean.

Vidakis, I. (2015). The Origins Of Energy Security: British Energy Policy In The Middle East (Selling the Same Horse Three Times!). Sosyoekonomi, 3, 31-45.

Vidakis, I., \& Baltos, G. (2013). Energy Security and Greece. Athens: DYROS Publishing.

Vidakis, I., \& Baltos, G. (2015). Security aspects of "Geoenergeia" and the significance of energy resources management in international politics. Geopolitics of energy, 37, 2-16.

Vidakis, I., Baltos, G., \& Balodis, J. (2017). Geopolitics of energy versus geoenergy of politics. Social sciences bulletin; Вестник социальных һаук, 2 (25), 38-55.

Wrigley, E. A. (2017). The supply of raw materials in the industrial revolution. In The Causes of the Industrial Revolution in England, (pp. 97-120). Routledge. 